\title{
PENGARUH MEDIA PEMBELAJARAN EDMODO TERHADAP HASIL BELAJAR PESERTA DIDIK PADA MATA PELAJARAN ADMINISTRASI SISTEM JARINGAN DI SMK AI-FALAH
}

\author{
Teti Mulyati, Milah Nurkamilah, Cecep Riki
}

\author{
Jurusan Pendidikan Teknologi Informasi, Fakultas Keguruan Ilmu Pendidikan \\ Universitas Muhammadiyah Tasikmalaya \\ e-mail: Tetimulyati2014@gmail.com
}

\begin{abstract}
ABSTRAKSI
Penelitian ini bertujuan untuk 1) Mendeskripsikan hasil belajar peserta didik menggunakan media Pembelajaran Edmodo pada mata pelajaran Administrasi Sistem Jaringan di SMK Al-Falah. 2) Mendeskripsikan pengaruh media pembelajaran Edmodo terhadap hasil belajar peserta didik pada mata pelajaran Administrasi Sistem Jaringan di SMK Al-Falah Tahun pelajaran 2019/2020. Jenis Penelitian yang digunakan adalah penelitian kuasi eksperimen dengan rancangan pretest posttest control group design. Populasi dalam penelitian ini adalah seluruh siswa kelas XI di SMK Al-Falah sebanyak 40 orang. pengambilan sampel yang sama dengan jumlah populasi yang ada, yaitu seluruh peserta didik sebanyak 40 orang. Proses pengacakan dilakukan terhadap penentuan kelas eksperimen dan kelas kontrol. Berdasarkan hasil pengacakan diperoleh kelas eksperimen yaitu XI TKJ A dengan jumlah peserta didik sebanyak 20 orang dan kelas kontrol yaitu kelas XI TKJ B dengan jumlah peserta didik 20 orang. Berdasarkan hasil analisis diperoleh 1) rata-rata hasil belajar peserta didik kelas eksperimen 80,25 lebih baik dari kelas kontrol yang memperoleh nilai rata-rata 74,15.2) Hasil uji independent t test nilai $t=6,508$ dengan pvalue $=0,000<\alpha=0,05$, sehingga menunjukan terdapat perbedaan rata-rata signifikan antara kelas eksperimen dan kelas control, artinya terdapat pengaruh media pembelajaran edmodo terhadap hasil belajar peserta didik.
\end{abstract}

Kata Kunci : Edmodo, Hasil Belajar, Administrasi Sistem Jaringan

\section{ABSTRACT:}

This study aims to 1) describe the learning outcomes of students using Edmodo learning media in the Network System Administration subject at SMK Al-Falah. 2) Describe the effect of Edmodo learning media on student learning outcomes in the Network System Administration subject at SMK Al-Falah in the 2019/2020 academic year. This type of research is a quasi-experimental study with a pretest posttest control group design. The population in this study were all students of class XI at SMK Al-Falah as many as 40 people. sampling the same as the existing population, namely all students as many as 40 people. The randomization process was carried out to determine the experimental class and control class. Based on the randomization results, it was obtained that the experimental class was XI TKJ A with 20 students and the control class was class XI TKJ B with 20 students. Based on the results of the analysis obtained 1) the average learning outcomes of students in the experimental class are 80.25 better than the control class who get an average value of 74.15. 2) The results of the independent $t$ test, the value of $t=6.508$ with $p$-value $=0.000<\alpha=0.05$, so that it shows that there is a significant average difference between the experimental class and the control class, meaning that there is an effect of Edmodo learning media on student learning outcomes.

Keywords: Edmodo, Learning Outcomes, Network System Administration

\section{PENDAHULUAN}

Proses pembelajaran yang semakin hari semakin meningkat dalam penggunaan media pembelajaran tidak lepas dari peran teknologi informasi. Hal ini terlihat dari guru dan peserta didik dengan penggunaan perangkat komputer dan internet di sekolah yang bertujuan untuk mendorong penyelenggaraan pembelajaran yang lebih menarik, aktif, dan kreatif seperti yang tercantum di dalam isi peraturan menteri pendidikan dan kebudayaan No. 65 tahun 2013 mencantumkan bahwa setiap guru wajib menerapkan teknologi informasi dan komunikasi secara terintegrasi, sistematis, dan efektif sesuai dengan situasi dan kondisi.

Penerapan teknologi informasi dalam proses pembelajaran juga dapat menciptakan suasana pembelajaran yang aktif, kreatif, efektif dan menarik bagi peserta didik. Dengan demikian, diharapkan pembelajaran yang memanfaatkan teknologi informasi dapat meningkatkan mutu dan kualitas pembelajaran. Peranan teknologi dalam dunia pendidikan memang tidak terelakkan lagi, pemerintah telah mengatur kebutuhan tentang teknologi di dalam peraturan perundang- undangan. Sesuai dengan peraturan, pemerintah telah mengatur kebutuhan tentang teknologi dalam peraturan perundang- undangan. Seperti tercantum dalam Permendiknas Nomor 16 Tahun 2007 mengenai Standar Kualifikasi Akademik dan Kompetensi Guru, kompetensi pedagogik guru SMA/SMK poin ke-5 mengatakan bahwa "Guru SMA/SMK harus memanfaatkan teknologi informasi dan komunikasi untuk kepentingan pembelajaran”. Kemudian dipertegas dalam Permendiknas Nomor 41 Tahun 2007 tentang Standar Proses, sesuai dengan Standar Kompetensi Lulusan dan Standar Isi maka prinsip pembelajaran yang digunakan pada 
poin ke-13 mengatakan bahwa "Pemanfaatan teknologi informasi dan komunikasi untuk meningkatkan efisiensi dan efektivitas pembelajaran".

Edmodo merupakan sebuah platform social network bagi guru siswa untuk berbagi ide, file, agenda kegiatan dan penugasan. Edmodo dirancang untuk menciptakan interaksi guru dan siswa yang menekankan pada komunikasi yang cepat, poling, penugasan, berbagi ide, dan banyak hal lagi. Sebagai pendidik, Edmodo memberikan fitur untuk berbagi file, link, tugas, nilai serta peringatan secara langsung kepada siswa. Sedangkan sebagai siswa, fitur yang diberikan adalah mereka dapat berkomunikasi dengan gurunya secara langsung, berdiskusi dengan siswa lain, mengirimkan tugas secara langsung dan banyak lagi. Maka dapat disimpulkan bahwa Edmodo adalah sebuah platform web dengan menggunakan konsep social networking berbasis Microblogging yang dikhususkan untuk membangun lingkungan belajar online yang aman untuk berbagi data, informasi serta konten-konten pendidikan baik berupa tulisan, dokumen, video, audio, foto, link yang dapat dibagikan baik oleh guru maupun siswa dan juga konten khusus berupa nilai, kuis, acara kegiatan, penugasan, dan polling yang hanya dapat dibagikan oleh guru.

Hasil pengamatan yang telah dilakukan peneliti selama mengajar menjadi guru praktikan di SMK AlFalah, kenyataannya bahwa peserta didik di kelas XI TKJ masih kurang memanfaatkan smartphone atau komputer yang dimiliki dan jaringan internet (Wifi) yang disediakan oleh sekolah untuk mencari materi pelajaran. Hal ini menunjukan, perlu ada upaya pemanfaatan teknologi informasi dalam proses pembelajaran. Kemudian hasil belajar peserta didik pada pelajaran Administrasi.

Sistem Jaringan diperoleh rata-rata nilai yaitu 74 sementara nilai KKM (Kriteria Ketuntasan Minimal) yaitu sebesar 75 sehingga masih berada dibawah nilai KKM (Kriteria Ketuntasan Minimal). Hal itu disebabkan karena materi administrasi sistem jaringan hanya bersifat teoritis dari mata pelajaran administrasi instalasi jaringan. sehingga peserta didik kurang tertarik mengikuti pembelajaran. peserta didik hanya melakukan praktek dengan cara simulasi menggunakan aplikasi cisco tracer. terutama menggunakan metode konvensional. Proses pembelajaran dengan metode konvensional lebih banyak guru yang aktif menyampaikan materi dengan sistem ceramah. Peserta didik lebih banyak menyimak. Metode pembelajaran konvensional cederung membosankan, membuat daya serap rendah, cepat hilang, karena bersifat menghafal.

Salah satu upaya untuk keberhasilan dalam belajar mengajar yaitu dengan penerapan teknologi ini adalah penggunaan Media Pembelajaran Edmodo. Hal ini disebabkan karena Media Pembelajaran Edmodo merupakan program aplikasi yang memiliki fitur yang lengkap dan terintegrasi dengan Internet. Media Pembelajaran Edmodo membantu guru untuk dapat memanfaatkan kelebihan dari media sosial dalam membangun sebuah kelas virtual berdasarkan pembagian kelas nyata yang sudah ada di sekolah. Di dalam kelas virtual tersebut berisi penugasan, kuis dan nilai yang diberikan setiap pembelajaran telah berakhir. Selain itu, Edmodo merupakan situs yang mudah digunakan selama seorang guru dan peserta didik bisa terhubung dengan adanya internet.

Dengan pemilihan media pembelajaran Edmodo peserta didik memiliki rasa ingin tahu yang tinggi untuk belajar Materi administrasi sistem jaringan dengan pembelajaran menggunakan Edmodo. Rasa ingin tahu peserta didik ditunjukan pada banyaknya komentar serta pertanyaan pada fitur comment setiap guru menguploadkan materi dan kuis pada setiap pertemuan. Setiap bertemu dikelas peserta didik sangat antusias mendiskusikan cara menggunakan media pembelajaran edmodo dengan guru. Hal ini disebabkan karena fiturfitur pada Edmodo sangat mudah dan menarik peserta didik untuk membuka semua fitur-fitur pada Edmodo dan mempelajarinya. Secara otomatis peserta didik paham bagaimana menggunakan aplikasi Edmodo untuk pembelajaran. Proses mendaftar pada akun Siswa sangat mudah. Peserta didik hanya tinggal membuka materi di Library. Setelah itu mengerjakan test secara online. Setelah selesai mengerjakan test secara online, peserta didik dapat langsung melihat hasilnya secara otomatis. peserta didik dengan semangat membaca semua yang ada dalam Edmodo. Hal itu disebabkan fitur pada Edmodo unik sehingga peserta didik tertarik untuk mempelajari aplikasi baru yang tidak diketahui sebelumnya.

Atas dasar inilah penulis tertarik untuk melakukan penelitian di SMK Al-Falah dengan judul penelitian pengaruh media pembelajaran Edmodo terhadap hasil belajar peserta didik pada mata pelajaran Administrasi Sistem Jaringan di SMK Al- Falah.

Adapun masalah yang dapat dirumuskan adalah sebagai berikut :

1. Bagaimana deskripsi hasil belajar peserta didik setelah pembelajaran menggunakan media pembelajaran Edmodo pada mata pelajaran Administrasi Sistem Jaringan di SMK Al-Falah ?

2. Bagaimana pengaruh media pembelajaran Edmodo terhadap hasil belajar peserta didik pada mata pelajaran Administrasi Sistem Jaringan di SMK Al-Falah Tahun Pelajaran 2019/2020 ?

Adapun tujuan dalam penelitian ini adalah :

1. Mendeskripsikan hasil belajar peserta didik menggunakan media Pembelajaran Edmodo pada mata pelajaran Administrasi Sistem Jaringan di SMK Al-Falah.

2. Mendeskripsikan pengaruh media pembelajaran Edmodo terhadap hasil belajar peserta didik pada mata pelajaran Administrasi Sistem Jaringan di SMK Al-Falah Tahun pelajaran 2019/2020.

Menurut Ariani dan Helsa [1] menyatakan bahwa Edmodo merupakan sebuah platform social network bagi guru siswa untuk berbagi ide, file, agenda kegiatan dan penugasan. Edmodo dirancang untuk menciptakan interaksi guru dan siswa yang menekankan pada komunikasi yang cepat, poling, penugasan, berbagi ide, dan banyak hal lagi. Sebagai pendidik, Edmodo memberikan fitur untuk berbagi file, link, tugas, nilai serta peringatan secara langsung kepada siswa. Sedangkan sebagai siswa, fitur yang diberikan adalah mereka dapat berkomunikasi dengan gurunya secara langsung, berdiskusi dengan siswa lain, mengirimkan tugas secara langsung dan banyak lagi.

Maka dapat disimpulkan bahwa Edmodo adalah sebuah platform web dengan menggunakan konsep social networking berbasis Microblogging yang dikhususkan untuk membangun lingkungan belajar online yang aman untuk berbagi data, informasi serta konten-konten pendidikan baik berupa tulisan, dokumen, video, audio, foto, link yang dapat dibagikan baik oleh guru maupun siswa dan juga konten khusus berupa nilai, kuis, acara kegiatan, penugasan, dan polling yang hanya dapat dibagikan oleh guru.

Berikut ilustrasi halaman utama dari aplikasi edmodo. Pada halaman utama terdapat menu teacher sebagai sarana guru melakukan login, menu student sebagai media peserta didik melakukan login untuk melihat 
materi dan kuis yang diberikan guru, dan menu parent yang digunakan orangtua untuk memantau proses pembelajaran yang dilakukan oleh peserta didik.

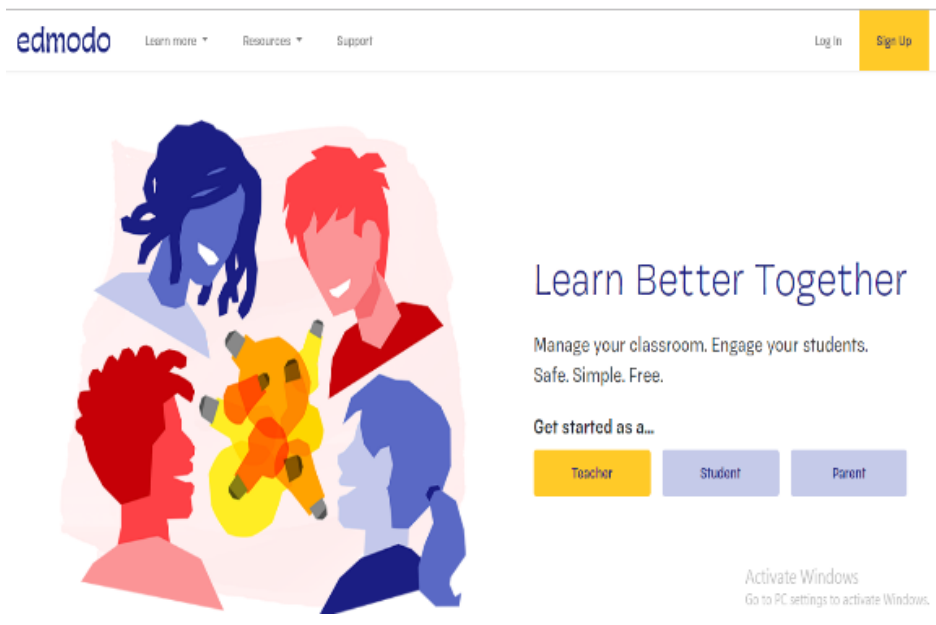

Gambar 1. Halaman Utama Media Pembelajaran Edmodo

\section{METODE PENELITIAN}

Sugiono [2] mengemukakan Metode penelitian merupakan cara ilmiah untuk mendapatkan data dengan tujuan dan kegunaan tertentu. Penelitian eksperimen dapat diartikan sebagai metode penelitian yang digunakan untuk mencari pengaruh perlakuan tertentu terhadap yang lain dalam kondisi yang terkendali.

Jenis Penelitian yang digunakan adalah penelitian kuasi eksperimen dengan rancangan pretest posttest control group design. Metode penelitian yang dilakukan dengan tujuan utama untuk mengetahui pengaruh media pembelajaran Edmodo terhadap hasil belajar peserta didik pada mata pelajaran Administrasi Sistem Jaringan di SMK Al-Falah serta dilakukan dengan menempuh langkah-langkah pengumpulan data, klasifikasi pengolahan data dan membuat data serta membuat kesimpulan lebih akurat.

Desain penelitian adalah semua proses penelitian yang diperlukan dalam perencanaan dan pelaksananaan penelitian dengan tujuan meminimalisir unsur kekeliruan (error). Pemilihan desain penelitian ditemukan oleh konsep pengujian yang akan dilakukan peneliti serta keberadaan data penelitian yang dibutuhkan.

Desain penelitian ini akan disajikan pada tabel dibawah ini:

Tabel 1. Pretest Posttest Control Group

\begin{tabular}{|l|l|c|c|c|}
\hline & Group & $\begin{array}{c}\text { Prete } \\
\text { st }\end{array}$ & $\begin{array}{c}\text { Perlakua } \\
\mathrm{n}\end{array}$ & $\begin{array}{c}\text { Postte } \\
\text { st }\end{array}$ \\
\hline $\mathrm{R}$ & Eksperimen & $\mathrm{O} 1$ & $\mathrm{X}$ & $\mathrm{O} 2$ \\
$\mathrm{R}$ & Kontrol & $\mathrm{O} 3$ & - & $\mathrm{O} 4$ \\
\hline \multicolumn{3}{|c|}{ (Sumber: Sugiyono, 2013. Metode Penelitian Pendidikan [3]) }
\end{tabular}

Ket :

$\mathrm{R}=$ Pengambilan sampel secara acak

$\mathrm{X}=$ Perlakuan pada kelas eksperimen

$\mathrm{O} 1=$ Pretest hasil belajar dengan menggunakan Edmodo

$\mathrm{O} 2=$ Posttest hasil belajar dengan menggunakan Edmodo

O3 $=$ Pretest pembelajaran konvensional O4 = Posttest pembelajaran konvensional Sumber Data

\section{Populasi}

Populasi adalah keseluruhan objek penelitian. Populasi dalam penelitian ini adalah seluruh siswa kelas XI di SMK Al- Falah sebanyak 40 orang.

\section{Sampel}

Sampel adalah sebagian yang diambil dari keseluruhan objek yang diteliti dan dianggap mewakili seluruh populasi. Dalam penelitian ini penulis menggunakan teknik pengambilan sampel dengan menggunakan total sampling. Menurut Arikunto [4] total random sampling adalah pengambilan sampel yang sama dengan jumlah populasi yang ada, yaitu seluruh peserta didik sebanyak

40 orang. Proses pengacakan dilakukan terhadap penentuan kelas eksperimen dan kelas kontrol. Berdasarkan hasil pengacakan diperoleh kelas eksperimen yaitu XI TKJ A dengan jumlah peserta didik sebanyak 20 orang dan kelas kontrol yaitu kelas XI TKJ B dengan jumlah peserta didik 20 orang.

\section{Analisa Data}

Setelah data dianalisis data yang digunakan dalam penelitian ini adalah:

1. Untuk mendeskripsikan hasil belajar peserta didik pada kelas kontrol dan kelas eksperimen digunakan analisis deskriptif. Analisis meliputi pengujian rata-rata (mean), median,dan varians.

Menurut Sugiono [3] Statistika Deskriptif adalah statistika yang digunakan untuk menganalisis data 
dengan cara mendeskripsikan atau menggambarkan data yang telah terkumpul sebagaimana adanya tanpa maksud membuat kesimpulan. Data deskriptif dapat disajikan kedalam tabel dan lain-lain yang mudah dibaca dan dipahami.

2. Untuk mendeskripsikan pengaruh media pembelajaran Edmodo digunakan statistika Inferensial.

\section{1) Uji Normalitas}

Menurut Nuryadi (2017:79) Uji Normalitas merupakan Suatu prosedur yang dimanfaatkan guna mengetahui bagaimana data tersebut merupakan bagian populasi yang terdistribusi normal atau terdapat pada sebaran normal. Yang dimaksud distribusi normal adalah bentuk distribusi tertentu yang mempunyai ciri- ciri berbentuk layaknya lonceng jika dibuat menjadi sebuah histogram. Uji normalitas digunakan untuk mengukur data berskala ordinal, interval, ataupun rasio. Apabila analisis memakai metode parametrik, maka persyaratan normalitas harus terpenuhi yaitu data berasal dari distribusi yang normal. Apabila data tidak berdistribusi normal, atau jumlah sampel sedikit dan jenis data adalah nominal atau ordinal maka metode yang digunakan merupakan statistic non parametik. Uji normalitas dimanfaatkan guna mengetahui bagaimana data itu diperoleh terdistribusi normal atau tidak. Uji normalitas menggunakan bantuan SPSS. Uji Kolmogorov smirnov digunakan dalam uji normalitas. Kriteria pengujian Ho ditolak jika nilai signifikansi $<\alpha=0,05$. Adapun hipotesisnya sebagai berikut:

Ho : sampel berdistribusi normal

$\mathrm{H} 1$ : sampel data berdistribusi tidak normal.

\section{2) Homogenitas Data}

Menurut Nuryadi [5] Uji Homogenitas merupakan suatu bentuk prosedur pengujian statistik yang digunakan untuk menunjukan bahwa dua atau lebih kelompok data sampel berasal dari populasi yang dimiliki variansi yang sama. Uji homogenitas menggunakan lavene Test SPSS.

3) Uji Independent t test.

Menurut Sugiono [3] Statistika Inferensial adalah rumusan yang dicantumkan untuk menjawab rumusan masalah. Rumusan masalah yang digunakan pada penelitian ini adalah deskripsi hasil belajar peserta didik setelah pembelajaran konvensional dan pembelajaran Edmodo serta pengaruh pembelajaran menggunakan media Edmodo Kelas XI TKJ A (Kelas Eksperimen)dan XI TKJ B (Kelas Kontrol) pada mata pelajaran Administasi sistem jaringan di SMK Al Falah. Pengujian hipotesis dengan bantuan SPSS Independent Sample T Test digunakan untuk menguji signifikansi beda rata-rata dua kelompok. Tes ini juga digunakan untuk menguji pengaruh variabel independent terhadap variabel dependent. Adapun untuk rumus Independent $\mathrm{t}$-test sebagai berikut:

$$
t_{\text {hitung }}=\frac{X 1-X 2}{\sqrt{\frac{(n 1-1) s_{1^{2}}+(n 2-1) s_{12}}{n 1+n 2-2}}\left(\frac{1}{n 1}+\frac{1}{n 2}\right)}
$$

(Sumber: Nuryadi, 2017. Dasar-dasar Statistik Penelitian)

Ket :

Xi $\quad$ : adalah rata-rata skor / nilai kelompok i. ni : adalah jumlah responden kelompok i

si2 : adalah variance skor kelompok i.

X1 : $\quad$ : Nilai post test Kelas Eksperimen

X2 : Nilai post test Kelas Kontrol

Hipotesis ujinya adalah :

Ho = Tidak terdapat pengaruh media pembelajaran Edmodo terhadap hasil belajar peserta didik pada mata pelajaran Administrasi Sistem jaringan di SMK Al-Falah.

$\mathrm{Ha}=$ Terdapat pengaruh media pembelajaran Edmodo terhadap hasil belajar peserta didik pada mata pelajaran Administrasi Sistem jaringan di SMK Al-Falah.

Media pembelajaran Edmodo dikatakan berpengaruh jika terdapat perbedaan rata-rata nilai post test kelas eksperimen dan kelas kontrol. adapun hipotesis statistikanya dinyatakan sebagai berikut:

Ho : $\mu \mathrm{a}=\mu \mathrm{b}$ (Tidak terdapat perbedaan rata- rata hasil belajar)

Ha : $\mu \mathrm{a} \neq \mu \mathrm{b}$ (Terdapat perbedaan rata-rata hasil belajar)

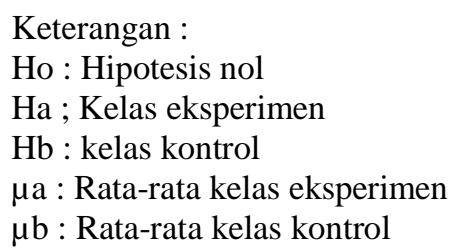

Perhitungan dilakukan menggunakan SPSS. Kriteria pengujian yaitu Ho ditolak jika nilai signifikansi lebih kecil dari $(<) \alpha: 0,05$.

\section{HASIL DAN PEMBAHASAN}

Pembelajaran yang dilakukan di kelas XI TKJ B sebagai kelas kontrol menggunakan metode konvensional pada proses kegiatan belajar mengajar yang dilaksanakan di kelas sebanyak empat pertemuan. Awal dari 
pembelajaran dilakukan dengan pembukaan yaitu memberi salam dan menanyakan keadaan peserta didik, mengabsen dan menjelaskan kompetensi dasar dan tujuan pembelajaran. selanjutnya menyampaikan materi pembelajaran dengan metode ceramah dari mulai pertemuan pertama tentang mail server, pertemuan kedua mengenai control panel hosting, pertemuan ketiga membahas share hosting server pertemuan keempat membahas virtual private server dengan alokasi waktu 3 x 45 menit setiap pertemuan. Selanjutnya peserta didik berdiskusi mengenai materi pembelajaran dan ada sesi Tanya jawab dengan guru tentang cakupan materi administrasi sistem jaringan. Setelah selesai pembelajaran dilakukan evaluasi berupa penilaian kepada peserta didik dengan soal test pada setiap pertemuan di akhir pembelajaraan .

Hasil pretest kelas kontrol dan kelas eksperimen mengenai nilai rata-rata (mean), nilaimedian, nilai varians, nilai max, dan nilai min disajikan pada tabel 3.8 berikut:

Tabel 2. Nilai pretest kelas kontrol (Kelas XI TKJ B) dan kelas eksperimen (KelasXI TKJ A)

\begin{tabular}{|l|c|c|}
\hline Nilai & $\begin{array}{r}\text { Kelas } \\
\text { Kontro }\end{array}$ & $\begin{array}{c}\text { Kelas } \\
\text { eksperimen }\end{array}$ \\
\hline Mean & 61,7 & 64.3 \\
\hline Median & 63,5 & 64.5 \\
\hline Varians & 67 & 38 \\
\hline Nilai Ma & 70 & 72 \\
\hline Nilai Mi & 40 & 55 \\
\hline
\end{tabular}

Berdasarkan tabel 2 terlihat bahwa hasil belajar peserta didik di kelas kontrol dan kelas eksperimen memiliki nilai rendah dibawah KKM dan hasilnya tidak berbeda. Data hasil belajar pada kelas kontrol mendapat nilai rata-rata 61,7 dan kelas eksperimen memiliki nilai rata-rata 64,3. Dari hasil pretest terdapat selisih tiga point antara kelas kontrol dan kelas eksperimen.

Hasil posttest kelas kontrol dan kelas eksperimen mengenai nilai rata-rata (mean), nilai median, nilai varians, nilai max, dan nilai min disajikan pada tabel 3.9 berikut :

Tabel 3. Nilai posttest kelas kontrol (Kelas XI TKJ B) dan kelas eksperimen (KelasXI TKJ A)

\begin{tabular}{|l|r|r|}
\hline Nilai & $\begin{array}{r}\text { Kelas } \\
\text { kontro }\end{array}$ & $\begin{array}{r}\text { Kelas } \\
\text { eksperime }\end{array}$ \\
\hline Mean & 74,15 & 80,25 \\
\hline Median & 75 & 80,5 \\
\hline Varians & 17 & 6 \\
\hline Nilai Ma & 79 & 85 \\
\hline Nilai Min & 65 & 65 \\
\hline
\end{tabular}

Pada tabel 3 menunjukan nilai posttest kelas kontrol dan kelas eksperimen mengalami peningkatan yaitu nilai rata-rata kelas control 74,15 dan kelas eksperimen memiliki nilai rata- rata 80,25. Setelah melakukan test hasil belajar berupa posttest menunjukan ada kenaikan nilai sebanyak 6,1 point $(6,1 \%)$. Dari Tabel dapat diperoleh kesimpulan bahwa nilai tes hasil belajar peserta didik kelas eksperimen setelah menggunakan media pembelajaran Edmodo lebih tinggi dibanding dengan kelas kontrol yang menggunakan metode konvensional.

Hasil penelitian menunjukan proses pembelajaran dengan menggunakan metode konvensional memiliki nilai rata-rata hasil belajar lebih rendah dibanding dengan proses pembelajaran menggunakan media Edmodo.

Sedangkan nilai rata-rata hasil belajar dengan menggunakan media pembelajaran Edmodo memiliki nilai lebih tinggi dengan mean: 81,25 , nilai median : 81,5, nilai varians : 6 dan nilai min : 76. Nilai hasil belajar kelas eksperimen dengan menggunakan media pembelajaran Edmodo melebihi KKM yaitu $>75$.

Maka dari itu, guru perlu meningkatkan aktifitas dalam penggunaan media pembelajaran Edmodo, misalnya guru mengadakan diskusi secara online tentang berita terbaru yang berkaitan dengan pembelajaran simulasi digital, guru memberikan soal-soal latihan atau kuis secara berkala sehingga banyak kegiatan belajar yang dapat dilakukan siswa dalam menggunakan Edmodo dan siswa menjadi lebih aktif dalam belajar.

Untuk mendapatkan hasil uji hipotesis digunakan perhitungan dengan menggunakan SPSS 25 dengan melakukan pengujian diantaranya:

1) Uji normalitas

Uji Normalitas digunakan untuk mengetahui pengaruh pembelajaran menggunakan media Edmodo dengan membandingkan nilai pretest antara Kelas Eksperimen (media Edmodo) dan Kelas Kontrol (Konvensional). Dengan test normalitas akan diukur perbedaan proses pembelajaran dengan media Edmodo dan konvensional pada mata pelajaran administrasi sistem jaringan.

Desain penelitian menggunakan metode quasy eksperimen dengan tes soal pretest pada kelas 
eksperimen dan kelas kontrol. Kelas ekperimen menerapkan pembelajaran menggunakan media Edmodo dan kelas kontrol menggunakan metode konvensional. Sehingga diperoleh hasil belajar peserta didik dari pre test kelas eksperimen dan kelas control.

Analisis data digunakan analisis deskkriptif dengan uji normalitas. Jika data penelitian normal.berguna untuk memaparkan data penelitian sama. Pengujian menggunakan SPSS 25 dengan membandingkan hasil belajar dari 20 peserta didik dari kelas eksperimen dan 20 peserta didik dari kelas kontrol.

Uji normalitas dilakukan terhadap nilai post test. Hasil uji normalitas untuk kedua kelas disajikan sebagai berikut:

Tabel 4.Hasil uji Normalitas

\begin{tabular}{|l|c|c|}
\hline \multicolumn{1}{|c|}{ Kelas } & Nilai $\alpha$ & Hasil \\
\hline $\begin{array}{l}\text { Kelas } \\
\text { Eksperimen }\end{array}$ & 0,200 & Normal \\
\hline $\begin{array}{l}\text { Kelas } \\
\text { Kontrol }\end{array}$ & 0,110 & Normal \\
\hline
\end{tabular}

Berdasarkan output SPSS dari hasil uji kolmogorov smirnov diperoleh untuk kelas eksperimen nilai signifikansi $0,200>\alpha=0,05$ maka Ho diterima, artinya data posttest pada kelas eksperimen berdistribusi normal. Sedangkan untuk kelas kontrol, nilai signifikansi diperoleh $0,110>\alpha=0,05$ maka Ho diterima, artinya data posttest kelas kontrol berasal dari populasi yang berdistribusi normal.

2) Uji Homogenitas dengan SPSS

Uji Homogenitas bertujuan untuk mengetahui suatu data dari dua kelompok bersifat omogen atau tidak. hasil data test of homogeneity of variance menunjukan nilai signifikansi (Sig) hasil belajar mata pelajaran Administrasi Sistem Jaringan peserta didik kelas eksperimen dan kelas kontrol adalah sebesar 0,052 >0,05. Ini menunjukan bahwa varian data hasil belajar siswa peserta didik kelas eksperimen dan kelas kontrol adalah sama atau homogen.

Tabel 5. Hasil uji Homogenitas

\begin{tabular}{|l|c|c|}
\hline \multicolumn{1}{|c|}{ Kelas } & $\begin{array}{l}\text { Lavene } \\
\text { statistic }\end{array}$ & sig \\
\hline $\begin{array}{l}\text { Kelas } \\
\text { Eksperimen } \\
\text { dan kelas } \\
\text { kontrol }\end{array}$ & 4,022 & 0,052 \\
\hline
\end{tabular}

3) Uji Independent Sample $\mathrm{T}$ test berupa rumus statistik (uji perbandingan perbedaan rata-rata hasil hasil belajar peserta didik antara kelas eksperimen dengan kelas kontrol)

Tabel 6. Hasil uji independent sample t test

\begin{tabular}{|l|c|c|}
\hline \multicolumn{1}{|c|}{ Kelas } & $\begin{array}{c}\mathrm{T} \\
\text { hitung }\end{array}$ & $\begin{array}{c}\text { Nilai } \\
\text { signifikan }\end{array}$ \\
\hline $\begin{array}{l}\text { Kelas } \\
\text { Eksperimen }\end{array}$ & 6,508 & 0,000 \\
\hline $\begin{array}{l}\text { Kelas } \\
\text { Kontrol }\end{array}$ & 6,508 & 0,000 \\
\hline
\end{tabular}

Berdasarkan output SPSS uji independent $\mathrm{t}$ test diperoleh nilai $\mathrm{t}$ hitung $=6,508$ dengan nilai signifikansi $0,000<\alpha=0,05$, maka dapat disimpulkan Ho di tolak. Artinya terdapat perbedaan rata-rata yang signifikan antara kelas eksperimen dan kelas kontrol sehingga dapat disimpulkan media pembelajaran Edmodo berpengaruh terhadap hasil belajar peserta didik pada mata pelajaran Administrasi Sistem Jaringan di SMK Al- Falah.

Berdasarkan analisis data hasil Penelitian dilaksanakan di SMK Al-Falah, dari hasil risetPeneliti menunjukan bahwa hasil belajar peserta didik dengan menggunakan media pembelajaran Edmodo di SMK Al-Falah mengalami peningkatan. Hal ini terlihat pada saat proses pembelajaran pada materi Administrasi Sistem Jaringan yang awalnya membosankan karena lebih banyak membahas teori jaringan, pembelajaran dengan media pembelajaran Edmodo memberikan kontribusi yang sangat tinggi pada peserta didik jurusan Teknik Komputer Jaringan karena pada saat memasuki media pembelajar Edmodo peserta didik harus membuat akun email di www.google.com untuk login pada akun siswa di Edmodo. Ini sangat mendukung pemahaman pada materi pembelajaran Internet. Selain 
itu pada saat belajar menggunakan media pembelajaran Edmodo peserta didik sangat bersemangat dan fokus pada materi pembelajaran Peserta didik sangat antusias pada materi administrasi sistem jaringan yang dilakukan pembelajaran dengan media Edmodo. . Pada saat guru mata pelajaran Administrasi Sistem Jaringan memakai media pembelajaran Edmodo penyampaian materi lebih optimal karena guru bisa memberikan berbagai metode yang relevan dengan bahan ajar yang disampaikan.Terlihat dari hasil uji hipotesis yang menunjukan Terdapat pengaruh rata-rata yang signifikan antara kelas kontrol dan kelas eksperimen. Dengan media pembelajaran Edmodo terhadap hasil belajar peserta didik kelas XI TKJ A dan TKJ B pada mata pelajaran administrasi sistem jaringan di SMK Al Falah. Pada kelas eksperimen peserta didik yang mendapat nilai rata-rata 80,25 di atas KKM (75) sebanyak 100\% (20 anak). Pada kelas kontrol yang mendapat nilai rata-rata peserta didik 74,15 di bawah KKM (75) sebanyak 90\% (20 anak). Artinya, secara individual kelas eksperimen dikatakan tuntas karena telah mencapai target yaitu $100 \%$. Secara kelompok, rata-rata kelas eksperimen sebesar 80,25 (di atas KKM) dan rata-rata kelas control 75,50. Artinya, secara kelompok penggunaan media Edmodo pada model pembelajaran Administrasi Sistem jaringan di Kelas XI TKJ A dengan kelas eksperimen telah berhasil dan Ho ditolak. Ini sejalan dengan hasil riset Azizah (2018) Pengaruh Model Pembelajaran E-learning Berbasis Edmodo Untuk Meningkatkan pemahaman konsep Matematis pada peserta didik di SMA. Dan berlawanan dengan hasil riset Muhammad (2015) dengan judul Hubungan penggunaan media pembelajaran Edmodo dengan hasil belajar siswa pada mata pelajaran simulasi digital di SMK Negeri Gombong yang menunjukan tidak ada hubungan antara media pembelajaran Edmodo dengan hasil belajar siswa.

Interaksi guru dengan peserta didik melalui media pembelajaran Edmodo sejalan dengan pendapat Ariani dan Helsa (2019) dari bukunya yang berjudul Desain Kelas Digital Menggunakan Edmodo dan Schoology yang memngemukan mengenai desain Edmodo yang memberi fasilitas kepada guru dan peserta didik melalui tempat yang private untuk saling berinteraksi, berkolaborasi dan berbagi konten informasi yang lain. Dengan media pembelajaran Edmodo guru bisa memperbaiki kesalahankesalahan yang dilakukan oleh peserta didik, mengirim nilai, tugas dan kuis untuk peserta didik. Peserta didik bisa mengemukakan pertanyaan dan meminta beberapa tugas yang bisa diselesaikan sebagai tugas rumah dan melihat tugas atau materi pelajaran. Antara guru dan peserta didik bisa terjadi suatu diskusi melalui topik yang diposting agar bisa didiskusikan di antara peserta didik.

Beberapa kelebihan media pembelajaran Edmodo yang digunakan pada penelitian di SMK AlFalah diantaranya menjadikan pembelajaran tidak tergantung pada waktu dan tempat. Selain pembelajaran dilaksanakan di kelas, peserta didik bisa membuka materi dan mengerjakan kuis dirumah. Peserta didik sangat antusias belajar menggunakan media pembelajaran Edmodo karena aplikasi ini sama dengan media social yang sedang disukai remaja saat ini.Media pembelajaran Edmodo Meringankan pekerjaan guru untuk memberikan penilaian kepada peserta didik melalui kolom kuis.

Media pembelajaran Edmodo mampu membuat kelas lebih dinamis, hal itu disebabkan adanya kemungkinan interaksi guru dengan peserta didik ataupun antar peserta didik dengan rekannya dalam menyelesaikan pelajaran melalui kolom comment ketika guru memasukan materi pada menu post di media pembelajaran Edmodo. Dengan media pembelajaran Edmodo peserta didik lebih aktif bertanya kepada guru dan berdiskusi dengan peserta didik yang lain sehingga materi pembelajaran terserap dengan sempurna. Selain itu media pembelajaran Edmodo mendorong lingkungan virtual kolaboratif yang membantu pembelajaran berbasis proses pada mata pelajaran administrasi sistem jaringan di SMK Al-Falah.

Data penelitian diambil dari sampel 20 orang peserta didik pada kelas XI TKJ A sebagai eksperimen menggunakan media pembelajaran Edmodo dan sampel 20 orang peserta didik XI TKJ B sebagai kelas kontrol dengan pembelajaran secara konvensional. Terdapat perbedaan yang signifikan dilihat dari minat belajar peserta didik antara kelas kontrol dan kelas eksperimen. Peserta didik lebih fokus belajar karena fitur media pembelajaran Edmodo sejenis dengan aplikasi facebook sekolah yang menarik karena didalammya terdapat pembelajarn virtual yang memiliki varian metode pembelajaran yang beraneka ragam dan merangsang minat belajar peserta didik. Pada saat pembelajaran peserta didik lebih aktif bertanya kepada guru ketika kesulitan membuka materi atau mengerjakan soal kuis yang diberikan oleh guru.

Sementara pembelajaran kelas kontrol dengan menggunakan metode konvensional cenderung monoton dan peserta didik kurang focus pada materi pembelajaran yang diberikan oleh guru. Hal ini disebebkan pembelajaran dengan metode konvensional cenderung membosankan. Berdasarkan hasil penelitian nilai kelas eksperimen lebih tinggi dibanding kelas kontrol. Maka berdasarkan hasil belajar peserta didik media pembelajaran Edmodo berpengaruh terhadap hasil belajar peserta didik pada mata pelajaran administrasi sistem jaringan di SMK Al-Falah.

\section{KESIMPULAN}

Berdasarkan analisis data dan hasil penelitian yang telah dilakukan mengenai pengaruh media pembelajaran Edmodo terhadap hasil belajar peserta didik pada mata pelajaran Administrasi Sistem Jaringan di SMK Al-Falah, dapat disimpulkan bahwa:

1. Hasil belajar kelas eksperimen menunjukan nilai rata-rata yaitu 81,25 lebih baik dari kelas kontrol dengan nilai rata-rata 74,15 sehingga menunjukan pengaruh positif terhadap data penelitian karena nilai hasil belajar naik 6,1 poin.

2. Berdasarkan hasil analisis uji hipotesis menggunakan SPSS 25 diperoleh nilai t hitung $=6,508$ menunjukan ada beda signifikansi dari sig bahwa lebih besar dari $t$ tabel dengan signifikansi $0,000<\alpha$ $=0,05$, yang artinya terdapat perbedaan rata-rata antara kelas eksperimen dan kelas kontrol, sehingga dapat disimpulkan terdapat pengaruh media pembelajaran Edmodo terhadap hasil belajar peserta didik pada mata pelajaran Administrasi Sistem Jaringan di SMK Al-Falah. 


\section{DAFTAR PUSTAKA}

[1] Ariani and Helsa, Desain Kelas Digital Menggunakan Edmodo dan Schoology. Yogyakarta: CV Budi Utama, 2019.

[2] Sugiyono, Metode Penelitian Kuantitatif Kualitatif dan R\&D. Bandung: AlfaBeta, 2006.

[3] Sugiyono, Metode Penelitian Kuantitatif Kualitatif dan R\&D. Bandung: AlfaBeta, 2016.

[4] Suharsimi Arikunto, Prosedur penelitian : suatu pendekatan praktik. Jakarta: Rineka Cipta., 2013.

[5] Nuryadi, Tutut Dewi A, Endang Sri U, and M. Budiantara, Dasar-dasar Statistik Penelitian, 1st ed. Yogyakarta: SIBUKU MEDIA, 2017.

\section{Biodata Penulis}

Teti Mulyati Lulus S1 tahun 2020 pada program studi Pendidikan Teknologi Informasi di Fakultas Keguruan dan Ilmu Pendidikan, Universitas Muhamamdiyah Tasikmalaya, Jawa Barat.

Milah Nurkamilah merupakan salah satu dosen di program studi Pendidikan Teknologi Informasi di Fakultas Keguruan dan Ilmu Pendidikan, Universitas Muhamamdiyah Tasikmalaya, Jawa Barat.

Sulidar Fitri merupakan salah satu dosen di program studi Pendidikan Teknologi Informasi di Fakultas Keguruan dan Ilmu Pendidikan, Universitas Muhamamdiyah Tasikmalaya, Jawa Barat. 